\title{
Effect of restricted emissions during Covid-19 lockdown on air quality in Rabat - Morocco
}

\author{
Elass K. ${ }^{1 *}$, Eddaif A. ${ }^{1}$, Radey 0. ${ }^{1,2}$, Aitzaouit 0. ${ }^{1,2}$, Yakoubi M.E. ${ }^{1,2}$ and Chelhaoui Y. ${ }^{3}$ \\ ${ }^{1}$ Environmental Metrology Laboratory, Ecole Nationale Supérieure des Mines de Rabat (ENSMR), BP: 753 Agdal-Rabat, Morocco \\ ${ }^{2}$ Research Laboratory of Applied Geophysics, Geotechnics, Engineering Geology and Environment, (L3GIE), Ecole Mohammadia \\ d'Ingénieurs (EMI), B.P. 765 Agdal-Rabat, Morocco \\ ${ }^{3}$ General Directorate of Meteorology (DGM), Hay Hassani, B.P. 8106 Casa-Oasis, Casablanca, Morocco \\ Received: 06/08/2020, Accepted: 08/08/2020, Available online: 11/09/2020 \\ *to whom all correspondence should be addressed: e-mail: khelass@gmail.com \\ https://doi.org/10.30955/gnj.003431
}

\section{Graphical abstract}

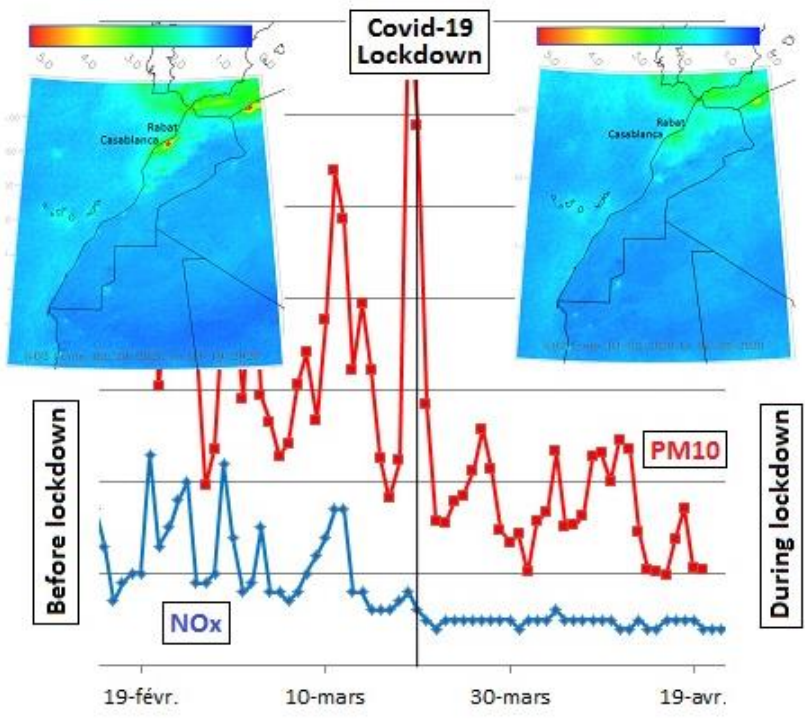

\begin{abstract}
The effect of restricted human activities due to the COVID19 pandemic in Rabat city (Morocco) was studied, by analysing data of five criteria pollutants (NO, $\mathrm{NO}_{2}, \mathrm{PM}_{2.5}$, $\mathrm{PM}_{10}$, and $\mathrm{O}_{3}$ ) to highlight the effectiveness of restricted emissions on air quality. Overall, drastic reductions on NO (up to $-94 \%$ ), $\mathrm{NO}_{2}$ (up to $-51 \%$ ), $\mathrm{PM}_{2.5}$ (up to $-45 \%$ ), and $\mathrm{PM}_{10}$ (up to $-53 \%$ ) concentrations were observed during lockdown period compared to the first period (before lockdown). Spaceborne $\mathrm{NO}_{2}$ column observations from TROPOMI on board Sentinel-5P, reveal unprecedented $\mathrm{NO}_{2}$ decreases (up to $-60 \%$ ). By contrast, an increase of approximately $20 \%$ in ozone mean concentrations was observed, probably related to the reduction of nitrogen oxides and also of fine particles $\left(\mathrm{PM}_{2.5}\right)$ which leads to less scavenging of $\mathrm{HO}_{2}$ and as a result greater $\mathrm{O}_{3}$ production.
\end{abstract}

Keywords: Coronavirus, lockdown, anthropogenic emissions, air quality, $\mathrm{NOx}, \mathrm{PM}, \mathrm{O}_{3}$.

\section{Introduction}

There is significant evidence that air pollution is associated with premature mortality (Lelieveld et al., 2015) and adverse health effects. According to the World Health Organization, 4.6 million individuals die annually from diseases and illnesses directly related to poor air quality (Cohen et al., 2017). Particulate matter with an aerodynamic diameter lower than $2.5 \mu \mathrm{m}$ and $10 \mu \mathrm{m}\left(\mathrm{PM}_{2.5}\right.$ and $\mathrm{PM}_{10}$ ), nitrogen oxides (NOx) and tropospheric ozone $\left(\mathrm{O}_{3}\right)$ are one of the greatest environmental problems of developed countries, indeed they are considered among the most threatening air pollutants, in urban environments, in terms of harmful effects on human health associated with respiratory and cardiovascular diseases and mortality (Cohen et al., 2017; Pascal et al., 2013).

In late December 2019, an unknown infectious disease, later named COVID-19, was identified in Wuhan, China ( $\mathrm{Na}$ Zhu et al., 2020). The disease has rapidly spread from Wuhan to other areas and affected 196 countries worldwide by March 25, 2020, which raised intense attention internationally. To contain the escalation of the transmission of the virus, many countries have adopted dramatic measures to reduce human interaction, prohibiting private and public gatherings, restricting all forms of transportation (both within a city and across cities).

As a possible side effect of this unprecedented lockdown, human mobility and relevant production and consumption activities have since decreased significantly. Transport sector, industrial and manufacturing sector were heavily affected. But on the other hand, lockdown restrictions are expected to largely modify anthropogenic emissions of pollutants, both in terms of emitted mass and time variations (Menut et al., 2020). Several studies on the impact of lockdown measures on air quality have recently been published. Sicard et al. (2020) studied the effect of lockdown on air pollution in four Southern European cities (Nice, Rome, Valencia and Turin) and Wuhan (China). Compared to the same period in 2017-2019, strong 
reductions in $\mathrm{NO}_{2}$ mean concentrations were observed in all European cities, $\sim 53 \%$ at urban stations, comparable to Wuhan (57\%), reductions in $\mathrm{PM}_{2.5}$ and $\mathrm{PM}_{10}$ at urban stations were overall much smaller both in magnitude and relative change in Europe ( $\sim \%$ ) than in Wuhan ( $42 \%)$. By contrast, the daily $\mathrm{O}_{3}$ mean concentrations increased at urban stations by $24 \%$ in Nice, $14 \%$ in Rome, $27 \%$ in Turin, $2.4 \%$ in Valencia and $36 \%$ in Wuhan during the lockdown in 2020. The same findings have been reported by Nakada et Urban (2020) in São Paulo (Brazil), Tobías et al. (2020) in Barcelona (Spain), Collivignarelli et al. (2020) in Milan (Italy), Sharma et al. (2020) in 22 cities covering different regions in India.

On the other hand, Bauwens et al. (2020); Tobías et al. (2020) have used spaceborne $\mathrm{NO}_{2}$ column data from two high-resolution instruments, Tropospheric Monitoring Instrument (TROPOMI) on board Sentinel-5 Precursor and Ozone Monitoring Instrument (OMI) on Aura. Exceptional decreases in $\mathrm{NO}_{2}$ columns were observed over widespread areas in China, Europe, Latin America, and the United Sates.

Morocco was confirmed as one of the countries affected by COVID-19, when the first case was confirmed in Casablanca on March 2, 2020. The government reacted decisively to the threat of the pandemic and declared a "health state of emergency" that went into effect on March 20 and included a nationwide lockdown. In this study, we carry out a rigorous investigation into this issue and estimate how lockdown affected air quality of Rabat (Capital city of Morocco), by studying the evolution of the nitrogen oxides ( $\mathrm{NO}$ and $\mathrm{NO}_{2}$ ), particulate matter $\left(\mathrm{PM}_{2.5}\right.$ and $\left.\mathrm{PM}_{10}\right)$, and ozone $\left(\mathrm{O}_{3}\right)$ concentrations determined before lockdown (from February 20 to March 19) and during the lockdown (from March 20 to April 20).

\section{Materials and methods}

Rabat, capital city of Morocco, is located on the Atlantic coast, with an urban population of approximately 580,000 (2014) and a metropolitan population of over 1.2 million. Rabat is characterized by a Mediterranean climate with an annual mean air temperature of $15^{\circ} \mathrm{C}$ (from $7{ }^{\circ} \mathrm{C}$ in January to $25{ }^{\circ} \mathrm{C}$ in August) and belongs to the sub-humid bioclimatic zone with an average annual precipitation of $560 \mathrm{~mm}$.

During the studied period, the real-time monitoring data were provided by the automatic monitoring station of the Atmosphere Competence Center (PCMA) installed in the campus of the national higher school of mining of Rabat, using standard methods and equipment. Thermo scientific model 42i NO- $\mathrm{NO}_{2}-\mathrm{NOx}$ analyzers, which are based on the most common used technique (chemiluminescence) for nitrogen oxides measurements. Ozone Analyzer O342e from ENVEA, using LED-based UV photometry technology, for $\mathrm{O}_{3}$ measurements. Particulate matter $\left(\mathrm{PM}_{2.5}, \mathrm{PM}_{10}\right)$ was determined with PALAS FIDAS ${ }^{\circledR} 200 \mathrm{E}$ continuous particle monitor, using an optical particulate monitoring spectrometer.

The concentrations of $\mathrm{NO}, \mathrm{NO}_{2}, \mathrm{PM}_{2.5}, \mathrm{PM}_{10}$, and $\mathrm{O}_{3}$ were obtained at 15-minute intervals. Experimental data were initially analyzed to identify spurious data and values were organized in spread sheets as 1-hour means. Daily averages (24 h) have then calculated for the periods before (February 20th to March 19th) and during the lockdown (March 20th to April 20th), assessing the variation in the mean concentration $\left(\mu \mathrm{g} \mathrm{m}^{-3}\right)$ between both periods, and their relative change (\%).

In parallel, remote sensing $\mathrm{NO}_{2}$ data, obtained by the Copernicus Sentinel-5 Precursor Tropospheric Monitoring Instrument (S5p/TROPOMI), has been used to assess tropospheric $\mathrm{NO}_{2}$ background levels in a high resolution $\left(3.5 \times 7 \mathrm{~km}^{2}\right)$ continuous area (lalongo et al., 2020).

In order to be able to interpret the evolution of pollutant concentrations before and during the confinement, meteorological parameters (temperature, relative humidity, and wind speed) were also determined. For this, the ERA5 data (http://cds.climate.copernicus.eu/ cdsapp\#!/dataset/reanalysis-era5-single-levels?tab=form) were collected for the 2 studied periods. These meteorological data are reanalyses available at a spatial resolution of $0.25^{\circ}$ and a temporal resolution of 1 hour.

\section{Results and discussion}

\subsection{Meteorological data analysis for reference period selection}

Meteorological data analysis is essential considering that weather phenomena have a massive influence on air quality. As shown in Table 1, average daily precipitation illustrates a similar situation between the lockdown and before lockdown periods, with low precipitation during the lockdown period. The recorded rainfall shows a total of about $2 \mathrm{~mm} \mathrm{~d}^{-1}$. Furthermore, there were negligible variations in temperature with a variation of less than $1^{\circ} \mathrm{C}$ between periods. The average wind speeds over the periods are also very similar. Overall, it can be concluded that the conditions are similar for the two periods, thus preventing an overestimation of air quality.

Table 1. Averaged meteorological parameters observed in Rabat city before and during the lockdown

\begin{tabular}{|c|c|c|c|}
\hline & $\begin{array}{c}\text { Temperature } \\
{ }^{\circ} \mathrm{C} \\
\end{array}$ & $\begin{array}{l}\text { Wind speed } \\
\qquad \mathrm{M} \mathrm{s}^{-1}\end{array}$ & $\begin{array}{l}\text { Precipitation } \\
\mathrm{mm} \mathrm{d}^{-1}\end{array}$ \\
\hline Mean BL & 15,8 & 2,5 & 0,2 \\
\hline Mean DL & 16,4 & 2,9 & 2,1 \\
\hline Difference & 0,6 & 0,4 & 1,9 \\
\hline
\end{tabular}

BL: Before Lockdown

DL: During Lockdown

\subsection{Air quality monitoring}

Experimental results were obtained from February 20 to April 20, 2020 at PCMA monitoring station. The obtained results are shown in table 2 and presented in Figures 1-4, respectively, for nitrogen oxides ( $\mathrm{NO}$ and $\mathrm{NO}_{2}$ ), particulate matter $\left(\mathrm{PM}_{2.5}\right.$ and $\left.\mathrm{PM}_{10}\right)$, and ozone $\left(\mathrm{O}_{3}\right)$. The amplitude of the concentration variation (ACV) was calculated to assess relative change (\%) comparing the lockdown period to before lockdown, using the equation; 


$$
\operatorname{AVC}=\frac{\mathrm{y}-\mathrm{x}}{\mathrm{x}} \times 100 \%
$$

where $x$ and $y$ are the mass concentrations of a substance of interest before and during the control period for Covid19 , respectively.

\subsubsection{Nitrogen oxides}

From the obtained results, as shown in Figure 1, exceptional decreases in nitrogen oxides levels were observed in the studied area. A decrease in the concentrations of $\mathrm{NO}$ (from 1.7 to $0.1 \mu \mathrm{g} \mathrm{m}{ }^{-3}$ ) and $\mathrm{NO}_{2}$ (from 8.6 to $4.2 \mathrm{\mu g} \mathrm{m}^{-3}$ ) was recorded, which corresponds to an AVC of $-94 \%$ and $-51 \%$, respectively. This could be explained by the containment measures against the spread of the Covid-19, which caused sharp reductions in traffic and industrial activities. The magnitude of changes was similar to those recorded in European cities ( $52 \%$ ) and Wuhan in China (57\%), where automobile exhausts are the major source of NOx (Sicard et al., 2020; Tobías et al., 2020).

Table 2. Mean concentrations of $\mathrm{NO}, \mathrm{NO}_{2}, \mathrm{PM}_{2.5}, \mathrm{PM}_{10}, \mathrm{O}_{3}$, measured in Rabat city before and during the lockdown

\begin{tabular}{|c|c|c|c|c|c|}
\hline & $\begin{array}{c}\text { NO } \\
\mu \mathrm{g} \mathrm{m}^{-3}\end{array}$ & $\begin{array}{c}\mathrm{NO}_{2} \\
\mu \mathrm{g} \mathrm{m}^{-3}\end{array}$ & $\begin{array}{l}\mathrm{PM}_{2.5} \\
\mu \mathrm{g} \mathrm{m}^{-3}\end{array}$ & $\begin{array}{c}\mathrm{PM}_{10} \\
\mu \mathrm{g} \mathrm{m}^{-3}\end{array}$ & $\begin{array}{c}O_{3} \\
\mu \mathrm{g} \mathrm{m}^{-3}\end{array}$ \\
\hline Mean BL & 1,7 & 8,6 & 17,1 & 36,4 & 35,1 \\
\hline Mean DL & 0,1 & 4,2 & 9,4 & 17,1 & 43,7 \\
\hline $\begin{array}{c}\text { Variation } \\
\text { in } \%\end{array}$ & -94 & -51 & -45 & -53 & +20 \\
\hline
\end{tabular}

\section{BL: Before Lockdown}

DL: During Lockdown

Nitrogen oxides ( $\left.\mathrm{NOx}=\mathrm{NO}_{2}+\mathrm{NO}\right)$ are among the main drivers in air quality degradation in urban centers, due to their role as catalysts of tropospheric ozone formation, and as precursors of secondary inorganic aerosols, with consequences for climate and human health (Lelieveld et al., 2015). NOx emissions are mainly generated by combustion processes from anthropogenic pollution sources including transportation, energy production and other industrial activities (He et al., 2020a, 2020b; Wang et al., 2017).

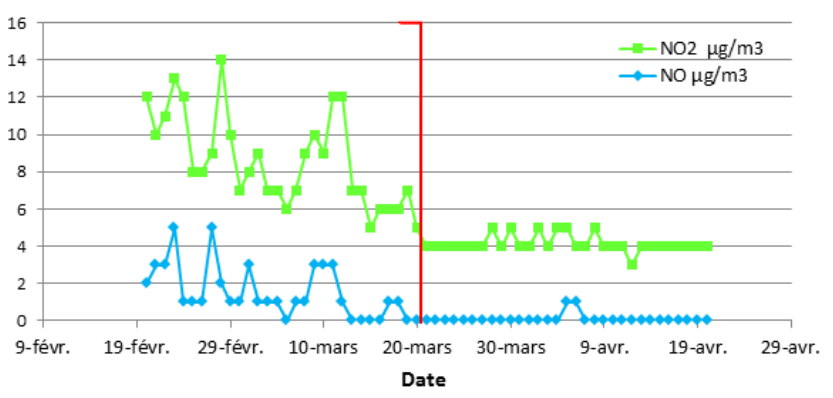

Figure 1. Daily NO and NO2 mean concentrations ( $\mu \mathrm{g} \mathrm{m}^{-3}$ ) determined at PCMA monitoring station from February 20, 2020 to April 20, 2020 in Rabat - Morocco

Daily NOx concentrations decrease is mainly attributed to the containment measures against the spread of the Covid19 , which caused sharp reductions in road traffic and fossil combustion. Recent researches have demonstrated that traffic emissions from heavy-duty diesel trucks are major sources of nitrogen oxides (Nakada et Urban, 2020; Wang et al., 2020) and is considered to be responsible for over half of NOx emissions and represents a higher proportion in urban areas.

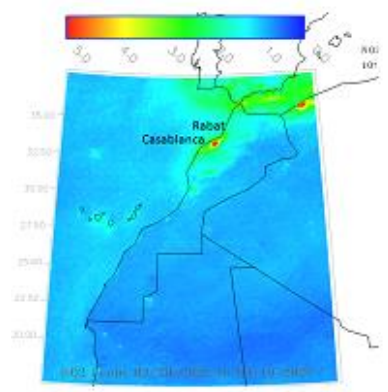

(a)

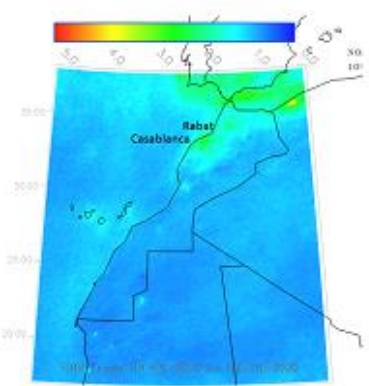

(b)
Figure 2. Average TROPOMI NO 2 tropospheric columns over Morocco (E15 molecules/ $\mathrm{cm}^{2}$ ), (a) before and (b) during the lockdown

On the other hand, $\mathrm{NO}_{2}$ emissions were measured using TROPOMI instruments through Copernicus Sentinel-5P satellite. The satellite image (Figure 2) provide comparison between the average of concentrations from 20 February to 19 March 2020 (panel a) and the average of concentrations from 20 March to 20 April 2020 (panel b). The $\mathrm{NO}_{2}$ emissions reduced up to $60 \%$ due to lockdown, especially across the major cities such as Casablanca and Rabat, thus confirming the measures observed at PCMA monitoring station. Several studies have used satellite observations of $\mathrm{NO}_{2}$ columns to assess the impact of covid19 (Nakada et Urban, 2020; Tobías et al., 2020; ZambranoMonserrate et al., 2020).

\subsubsection{Particulate matter}

The particulate matter (PM) showed the same behavior (Figure 3) as the nitrogen oxides during the Covid-19 control period compared with the reference period, in fact the mean concentrations decreased (from 17.1 to $9.4 \mu \mathrm{g}$ $\mathrm{m}^{-3}$ ) and from (36.4 to $17.1 \mathrm{\mu g} \mathrm{m}^{-3}$ ), which corresponds to an AVC of $-45 \%$ and $-53 \%$, respectively, for $\mathrm{PM}_{2.5}$ and $\mathrm{PM}_{10}$. The higher decrease in $\mathrm{PM}_{10}$ compared to $\mathrm{PM}_{2.5}$ could be due to its greater contribution from anthropogenic sources (Klimont et al., 2017). The main source of $\mathrm{PM}_{10}$ in the urban background is road traffic, combustion of fuels, industrial sources, construction works, dust resuspension, Saharan dust episodes (Querol et al., 2009), and regional air mass transport which could have an influence on PM to the point of reducing the effects of local emission reduction. Aerosol particles $\mathrm{PM}_{2.5}$ are also receiving worldwide attention, as they have a potential greater adverse effect on the health of human beings, especially on that part of the population living in urban areas influenced by high traffic density or industry (Dongarrà et al., 2010).

The reduction of $\mathrm{PM}_{10}(-53 \%)$ was likely attributable to the significant reduction in vehicular traffic given by the transfers restrictions imposed by the authorities considering that transports represent the main source of 
$\mathrm{PM}_{10}$ in Rabat. The effects of reducing local air pollution on $\mathrm{PM}_{10}$ concentrations might still be limited due to the contribution of long-range transported PM. Indeed, the back trajectory analysis portrayed that air quality in Rabat urban area is mainly affected by PM originating from the Mediterranean Basin (characterized by marine vessel emissions out of Western Europe and Northern Africa), local continental and from the near Atlantic Ocean (Othmani et al., 2020). The reduction of $\mathrm{PM}_{2.5}$ of $-45 \%$ can be attributed to the simultaneous reduction in the concentration of other pollutants such as $\mathrm{NH}_{3}$, volatile organic compounds (e.g. benzene), and NOx which act as precursors to the formation of secondary $\mathrm{PM}_{2.5}$ (Chen et al., 2017). Similar findings were reported by Nakada and Urban (2020) and Zambrano-Monserrate et al. (2020).

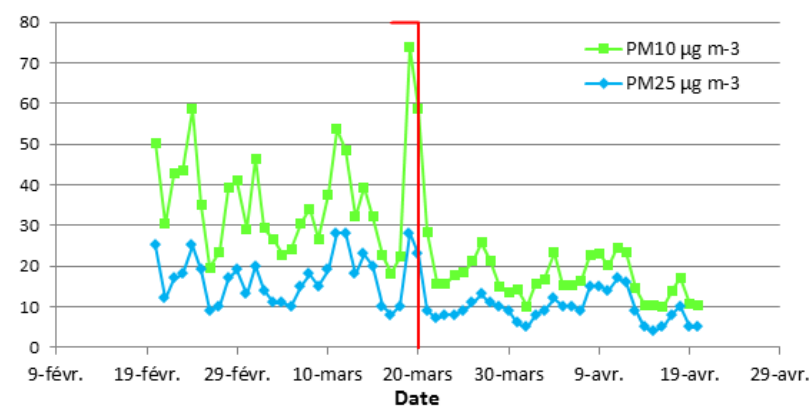

Figure 3. Daily $\mathrm{PM}_{2.5}$ and $\mathrm{PM}_{10}$ mean concentrations $\left(\mu \mathrm{g} \mathrm{m}^{-3}\right)$ determined at PCMA monitoring station from February 20, 2020 to April 20, 2020 in Rabat - Morocco

\subsubsection{Ozone}

By comparing mean concentrations before and during the lockdown, we observed that higher $\mathrm{O}_{3}$ concentrations occurred during the lockdown. The daily $\mathrm{O}_{3}$ mean concentrations increased considerably, from 35.1 to 43.7 $\mu \mathrm{g} \mathrm{m}^{-3}$ which corresponds to an AVC of $+20 \%$ (Figure 4 ). This result is consistent with the recent literatures, for example, Sharma et al. (2020) reported an increase in $\mathrm{O}_{3}$ in many cities covering different regions of India and Nakada et Urban (2020) observed an increase of approximately $30 \%$ in ozone concentrations in São Paulo.

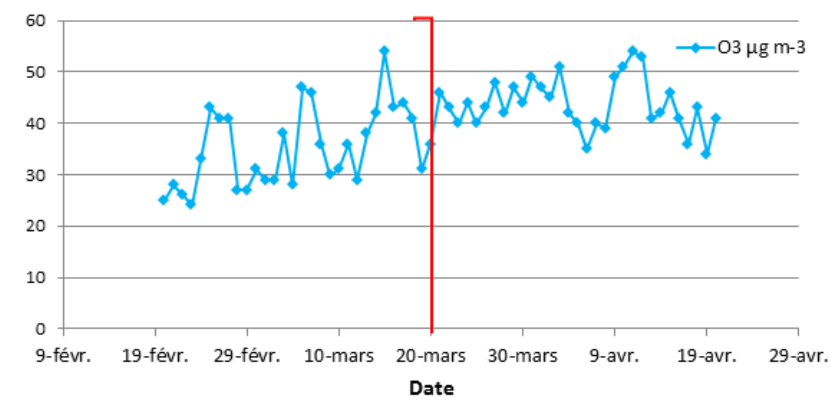

Figure 4. Daily $\mathrm{O}_{3}$ mean concentrations $\left(\mu \mathrm{g} \mathrm{m}^{-3}\right)$ determined at PCMA monitoring station from February 20, 2020 to April 20, 2020 in Rabat - Morocco

The photochemical processes related to tropospheric ozone formation have been extensively discussed in the literature. Ground-level $\mathrm{O}_{3}$ is subject to in situ chemical reactions and physical processes and is directly affected by precursor emissions, temperature, solar radiation and other meteorological factors. A number of studies have examined the role of anthropogenic and meteorological factors in the formation of ozone and concluded that meteorological factors were not negligible, but anthropogenic factors were dominant (Yu et al., 2019). Li et al. (2019a, 2019b) found that the increasing trend cannot be simply explained by changes in anthropogenic precursor [NOx (where $\mathrm{NOx}=\mathrm{NO}+\mathrm{NO}_{2}$ ) and volatile organic compound ( $\mathrm{VOC})$ ] emissions, this is mainly due to aerosol chemistry rather than photolysis. In the troposphere, NOx reacts with volatile organic compounds (VOCs) to form $\mathrm{O}_{3}$, and therefore, one would expect that $\mathrm{O}_{3}$ would have decreased along with NOx during the control period for Covid19, however, this was not the case. In fact, the daily $\mathrm{O}_{3}$ mean concentrations increased considerably (+20\%). The increase in $\mathrm{O}_{3}$ levels in the Rabat city can be explained by different possible combined causes. Firstly, the usual increase of insolation and temperatures $\left(\sim 3.7^{\circ} \mathrm{C}\right)$ from February to April leads to an increase in $\mathrm{O}_{3}$. Secondly, the decrease of nitrogen oxide $(-94 \%)$ reduces the $\mathrm{O}_{3}$ consumption (titration, $\mathrm{NO}+\mathrm{O}_{3}=\mathrm{NO}_{2}+\mathrm{O}_{2}$ ), and causes an increase of $\mathrm{O}_{3}$ concentrations. Thirdly, the decrease of $\mathrm{NOx}$ in a VOCs-limited environment might cause urban $\mathrm{O}_{3}$ to increase, as opposed to the behavior at the rural-regional background, which is mainly NOx-limited (Monks et al., 2015). Silva et al. (2017), reported that at low VOC/NOx ratios, a typical situation of polluted urban centers, the system is VOC-controlled, and reducing NOx at constant VOCs leads to an increase of ozone concentrations. Finally, the observed increases in $\mathrm{O}_{3}$ during the Covid-19 controls may be related to the observed decreases in fine particles. The decrease of $\mathrm{PM}_{2.5}$ (-45\%) promotes ozone formation due to the role of fine particles as scavenger of hydroperoxy radicals $\left(\mathrm{HO}_{2}\right)$ which would increase peroxy radical-mediated $\mathrm{O}_{3}$ production (Li et al., 2019a, 2019b). Liao and Seinfeld (2005) found that simulated surface layer $\mathrm{O}_{3}$ concentrations can be reduced by $25-30 \%$ due to heterogeneous reactions on fine particulate matter using a coupled global chemistry-aerosol-climate model.

\section{Conclusions}

As it could be expected, significant air quality improvements were observed during the lockdown in the studied area, a strong decrease in the mean concentrations of specific air pollutants was recorded, NO (up to -94\%), $\mathrm{NO}_{2}$ (up to $-51 \%$ ), $\mathrm{PM}_{2.5}$ (up to $-45 \%$ ), and $\mathrm{PM}_{10}$ (up to $-53 \%)$. Overall, the significant declines in NOx and PM concentrations are mainly attributed to the containment measures against the spread of the Covid-19, which caused sharp reductions in traffic and industrial activities. However, the reduction in nitrogen oxides and particulate matter emissions did not fully eliminate air pollution, and $\mathrm{O}_{3}$ actually increased (up to $+20 \%$ ). This result illustrates the importance of reactions that can occur between gaseous and particulate pollutants. Ozone increase can be explained by the lower titration of $\mathrm{O}_{3}$ by $\mathrm{NO}$ due to the strong reduction in local NOx emissions and by the drop in $\mathrm{PM}_{2.5}$ which can lead to less trapping of hydroperoxy 
radicals $\left(\mathrm{HO}_{2}\right)$, which would increase peroxy radicalmediated $\mathrm{O}_{3}$ production.

\section{Acknowledgments}

Authors would like to thank the AFD (Agence Française pour le Développement), the MEME (Ministre de l'Energie, des Mines et de l'Environnement), the DMN (Direction de la Météorologie Nationale, Maroc), the DGCL (Direction Général des Collectivités Locales), the FM6 (Fondation Mohammed VI pour la protection de l'environnement), the IMT-LD (Institut Mines Telecom - Lille Douai, ARIA Technology and the ENSMR (Ecole Nationale Supérieure des Mines de Rabat) for their support.

\section{References}

Bauwens M., Compernolle S., Stavrakou T., Muller J.F., van Gent J., Eskes H., Levelt P.F., Van Der A.R., Veefkind J.P., Vlietinck J., Yu H. and Zehner C. (2020), Impact of coronavirus outbreak on $\mathrm{NO}_{2}$ pollution assessed using TROPOMI and OMI observations, Geophysical Research Letters, 47, GL087978.

Chen T.-F., Chang K.-H. and Tsai C.-Y. (2017), Modeling approach for emissions reduction of primary PM 2.5 and secondary PM 2.5 precursors to achieve the air quality target, Atmospheric Research, 192, 11-18.

Cohen A.J., Brauer M., Burnett R., Anderson H.R., Frostad J., Estep K., et al. (2017), Estimates and 25-year trends of the global burden of disease attributable to ambient air pollution: an analysis of data from the Global Burden of Diseases Study 2015, Lancet, 389, 1907-1918.

Collivignarelli M.C., Abba A., Bertanza G., Pedrazzani R., Ricciardi P. and Miino M.C. (2020), Lockdown for CoViD-2019 in Milan: what are the effects on air quality? Science of the Total Environment, 732, 139280.

Dongarrà G., Manno E., Varrica D., Lombardo M. and Vultaggio M. (2010), Study on ambient concentrations of PM10, PM10-2.5, PM2.5 and gaseous pollutants. Trace elements and chemical speciation of atmospheric particulates, Atmospheric Environment, 44, 5244-5257.

He M.Z., Kinney P.L., Li T., Chen C., Sun Q., Ban J., Wang J., Liu S., Goldsmith J. and Kioumourtzoglou M.A. (2020a), Short- and intermediate-term exposure to $\mathrm{NO}_{2}$ and mortality: a multicounty analysis in China, Environmental Pollution, 114165.

He L., Zhang S., Hu J., Li Z., Zheng X., Cao Y., Xu G., Yan M. and Wu $Y$. (2020b), On-road emission measurements of reactive nitrogen compounds from heavy-duty diesel trucks in China. Environmental Pollution, 114280.

lalongo I., Virta H., Eskes H., Hovila J. and Douros J. (2020), Comparison of TROPOMI/Sentinel-5 Precursor $\mathrm{NO} 2$ observations with ground-based measurements in Helsinki, Atmospheric Measurement Techniques, 13, 205-218.

Klimont Z., Kupiainen K., Heyes C., Purohit P., Cofala J., Rafaj P., Borken-Kleefeld J. and Schöpp W. (2017), Global anthropogenic emissions of particulate matter including black carbon, Atmospheric Chemistry and Physics, 17, 8681-8723.

Lelieveld J., Evans J.S., Fnais M., Giannadaki D. and Pozzer A. (2015), The contribution of outdoor air pollution sources to premature mortality on a global scale, Nature, 525, 367-371.

Li K., Jacob D.J., Liao H., Shen L., Zhang Q. and Bates K.H. (2019a), Anthropogenic drivers of 2013-2017 trends in summer surface ozone in China, Proceedings of the National Academy of Sciences of the United States of America, 116, 422-427.
Li K., Jacob D.J., Liao H., Zhu J., Shah V., Shen L., Bates K.H., Zhang Q. and Zhai S. (2019b), A Two-Pollutant Strategy for Improving Ozone and Particulate Air Quality in China, Nature Geoscience, 12, 906-910.

Liao H. and Seinfeld J.H. (2005), Global impacts of gas-phase chemistryaerosol interactions on direct radiative forcing by anthropogenic aerosols and ozone, Journal of Geophysical Research, 110, D18208

Menut L., Bessagnet B., Siour G., Mailler S., Pennel R. and Cholakian A. (2020), Impact of lockdown measures to combat Covid-19 on air quality over western Europe, Science of the Total Environment, 741, 140426.

Monks P.S., Archibald A.T., Colette A., Cooper O., Coyle M., Derwent R., Fowler D., Granier C., Kathy S. Law, Mills G.E., Stevenson D.S., Tarasova O., Thouret V., von Schneidemesser E., Sommariva R., Wild O. and Williams M.L. (2015), Tropospheric ozone and its precursors from the urban to the global scale from air quality to short-lived climate forcer, Atmospheric Chemistry and Physics, 15, 8889-8973.

Zhu N., Zhang D., Wang W., Li X., Yang B., Song J., Zhao X., Huang B., Shi W., Lu R., Niu P., Zhan F., Ma X., Wang D., Xu W., Wu G., Gao G.F., and Tan W. (2020), A Novel Coronavirus from Patients with Pneumonia in China, 2019, New England Journal of Medicine, 382, 727-733.

Nakada L.Y.K. and Urban R.C. (2020), COVID-19 pandemic: Impacts on the air quality during the partial lockdown in São Paulo state, Brazil, Science of the Total Environment, 730, 139087.

Otmani A., Benchrif A., Tahri M., Bounakhla M., Chakir E., El Bouch M. and Krombi M. (2020), Impact of Covid-19 lockdown on $\mathrm{PM} 10, \mathrm{SO}_{2}$ and $\mathrm{NO}_{2}$ concentrations in Salé City (Morocco), Science of the Total Environment, 735, 139541.

Pascal M., Corso M., Chanel O., Declercq C., Badaloni C., Cesaroni G., et al. (2013), Assessing the public health impacts of urban air pollution in 25 European cities: results of the Aphekom project, Science of the Total Environment, 449, 390-400.

Querol X., Alastuey A., Pey J., Pandolfi M., Cusack M., Pérez N., Viana M., Moreno T., Mihalopoulos N., Kallos G. and Kleanthous S. (2009), African dust contributions to mean ambient PM10 mass-levels across the Mediterranean Basin, Atmospheric Environment, 43 (28), 4266-4277.

Sharma S., Zhang M., Anshika Gao J., Zhang H. and Kota S.H. (2020), Effect of restricted emissions during COVID-19 on air quality in India, Science of the Total Environment, 728, 138878.

Sicard P., De Marco A., Agathokleous E., Feng Z., Xu X., Paoletti E., Diéguez Rodriguez J.J. and Calatayud V. (2020), Amplified ozone pollution in cities during the COVID-19 lockdown, Science of the Total Environment, 735, 139542.

Silva C.M., da Silva L.L., Corrêa S.M. and Arbilla G. (2017), Speciation Analysis of Ozone Precursor Volatile Organic Compounds in the Air Basins of the Rio de Janeiro Metropolitan Area, Revista Virtual de Química, 9, 1887-1909.

Tobias A., Carnerero C., Reche C., Massagué J., Via M., Minguillon M.C., Alastuey A. and Querol X. (2020), Changes in air quality during the lockdown in Barcelona (Spain) one month into the SARS-CoV-2 epidemic, Science of the Total Environment, 726, 138540.

Wang S., Yu S., Yan R., Zhang Q., Li P., Wang L., Liu W. and Zheng X. (2017), Characteristics and origins of air pollutants in Wuhan, China, based on observations and hybrid receptor 
models, Journal of the Air \& Waste Management Association, 67, 739-753.

Wang Y., Yuan Y., Wang Q., Liu C., Zhi Q. and Cao J. (2020), Changes in air quality related to the control of coronavirus in China: Implications for traffic and industrial emissions, Science of the Total Environment, 731, 139133.

Yu Y., Wang Z., He T., Meng X., Xie S. and Yu H. (2019), Driving factors of the significant increase in surface ozone in the Yangtze River Delta, China, During 2013-2017, Atmospheric Pollution Research, 10, 1357-1364.

Zambrano-Monserrate M.A., Ruano M.A. and Sanchez-Alcalde L. (2020), Indirect effects of COVID-19 on the environment. Science of the Total Environment, 728, 138813. 